\title{
Virginia Woolf in the garden of forms
}

\begin{abstract}
For Virginia Woolf writing was always the site of a cognitive agone, which often appeared either in the guise of a perceptual euphoria or of a prostration. The agone is most than evident in the short stories, where traditional modes of narration implode under the strong metanarrative flavour and the struggle with the structure. The case of "In the Orchard", an experimental writing developed under the fascination of pictorial form, is exemplary in this perspective. In strong dialogue with the Impressionist and Post-impressionist avant-guard, a number of short stories make evidence of Woolf's obsession with visuality and form, with specific reference to this short story where a 'self-reflected' subject, in the guise of a young woman, occupies the foreground. The Miranda of "In the Orchard" is in fact surprised in its groping between the sphere of the intelligible and that of the optical reflection, scrutinised by a narrator who 'freezes' the scene into a repetitive writing writing, so as to let the reader look at it from different perspectives, with fresh eyes or even 'eyeless', recording 'crises' and 'progress' that are eventually shared by all the textual actors- author, character, narrator and reader.
\end{abstract}

Keywords: virginia woolf, forms, painters, autumnal woods, walter sickert, human, colour, images
Volume 3 Issue 5 - 2019

\author{
Rossana Bonadei \\ Università degli Studi di Bergamo, Italy
}

Correspondence: Rossana Bonadei, Università degli Studi di Bergamo, Italy, Email rossana.bonadei@unibg.it

Received: August 05, 2019 | Published: September 23, 2019

\section{Contexts}

You know, I imagine. But then you live in the world. You have a garden too, with trees against the sky, and a bonfire in the middle distance. I could make an exquisite story out of you-so don't imagine that all the insight is on your side. I can imagine you, from the moment you wake in the morning till you go to bed again, without leaving my chair.

Around the nineteen-twenties, Virginia Woolf was training herself to see the world through painters' eyes, especially those avant-gard painters promoted by Roger Fry and Clive Bell. And it was in reasoning on "the visual", in a sympathetic allegiance with the 'painters' of Bloomsbury (namely with her sister Vanessa, like her fascinated by subjects- mainly female subjects- she represented with eyes wide shut, or without eyes) ${ }^{i}$ that Woolf had come to a radical necessity of trying other methods of narrating, finding in the Victorian 'demon of description' the ghost to fight with. From the very beginning of her literary activity, many insights had prepared the final stroke and then given in Modern Fiction: so, in 1910, speaking of the mid-Victorian novel and praising some feeble innovation observed in a woman writer, she would say:

"Our ambition, on the other hand, is to put in nothing that need not to be there. What we want to be there is the brain and the view of life; the autumnal woods, the history of the whale fishery, and the decline of stage-coaching we omit entirely". ${ }^{2}$ The manifesto against description is progressively engrossed with examples and notions taken from literary genres: it is concerned with landscape theory and the revaluation of the visionary poet working with "half-shut eyes", iDiane Gillespie (1988) and Jane Dunn (1990) have given some seminal pivotal analysis of the writing and painting of the Stephen sisters, in the context of the Bloomsbury milieu and the Post-Impressionist agenda. A recent exploration of the close aesthetic 'dialogue' between the two sisters is in AA.VV., Vanessa Bell\&Virginia Woolf. Disegnare la vita, Ferrara, Sate,1996. On the intersections between writing and painting in Woolf's narrative see also the extended studies of Liliane Louvel (2002) and Flora De Giovanni (2007)- where the best description is "what the poet saw with his eyes shut when the landscape had melted indistinguibly into the mood". ${ }^{2}$ Once re-established the 'sense of place' over the material landscape, a time will come "when character will take on a different aspect under the novelist's hand, when he will be less fearful of the charge of unreality, less careful of the twitterings and chatterings which now make our puppets so animated and for the most part so ephemeral".

According to Woolf- here speaking in the name of the younger generation of writers- an 'excess' of details doomed to the destruction of the English literary tradition at the turn of the century: either writers see too much or they see wrongly, they are seduced by what is 'alien' and 'external' to life, which is too flickering- and yet too serious- to be enclosed in "magnificent apparatus" and "ill-fitted vestments". What 'life' is was made clear in quite peremptory tones by Virginia Woolf in a passage that has become a landmark in literary studies and often echoes in narrative studies; we take the liberty of recalling it here, as these words will be a useful background to the last part of our argument:

"Examine for a moment an ordinary mind on an ordinary day. The mind receives a myriad impressions- trivial, fantastic, evanescent, or engraved with the sharpness of steel. From all sides they come, an incessant shower of innumerable atoms... Is it not the task of the novelist to convey this varying, this unknown and uncircumscribed spirit, whatever aberration or complexity it may display, with as little mixture of the alien and external as possible?". ${ }^{3}$ It is a matter of looking at things differently, a matter of "eyes": novelists should close their own eyes and try to see the world with other eyes. Fascination with visual techniques and post-impressionist methods of representation is evident in many writings, from diary entries to letters (above all, those to Fry, Bell, her sister Vanessa, Raverat and T.S. Eliot), as well as in reviews and in many short pieces. Painting was becoming for her the new frontier of representation, the key to find an access to 'another scene'. In some short prose, such as "The Mark on the Wall", "Solid objects", "An Unwritten Novel”, "Kew Garden", "Blue and 
Green" (not pieces but "short things"- in Woolf's words), Woolf was working on the visual to review the narrative. Nothing of this writingand perhaps little of Modernist writing- could have existed without the fascination for visuality and the notion, then especially fostered by avant-gard painters, that an object 'becomes' what we see of it, corresponding to different images or different descriptions, according to time-scale, perspective, mood: and this happens in spite of shared conventions.

Life appears then a kaleidoscopic affair, that resists figure and description and whose expression calls not for figures but for "splashes" or "ekphrasis": "(3 october 1924) There are splashes in the outer air in every direction and under the surface wave that follow one another into dark forgotten corners...the writer is trying to catch and consolidate and consummate (whatever the world is for making literature) those splashes of yours". If the visual euphoria inspires a number of "short things" where colours (blue, green, yellow, red- the full colours of the Post-Impressionist canvas) are cognitive reagents to test perceptions and to reshape them in a "plastic" rather than in a lexical way, ${ }^{\text {ii }}$ the phantom haunts the writer with the nightmare of 'unwritable novels' and 'unspeaking heroes': in literature, the victim of this split is first of all the narrative subject- the Cartesian subject identified with the eye/ I- still left rather unproblematized in its authority to master the world through his gaze and his words. What avant-garde artists show and Woolf is debating is the option of an eye devoid of 'I', while a third eye is needed to select what is 'writable':

"Taste, sound, movement, a few words here, a gesture there, a man coming in, a woman going out, even the motor that passes in the street or the beggar who shuffles along the pavement, and all the reds and blues and lights and shades of the scene claim his attention and rouse his curiosity. He can no more cease to receive impressions than a fish in mid ocean can cease to let the water rush through his gills". For Woolf the purely visual inclines to the absence of a story, in spite of narration is a silence full of echoes, while, conversely, the verbal begins exactly where the visual fails, "because we know that it is hard for a painter to tell a story with his brush", ${ }^{5}$ or more precisely painters "must say what they have to say by shading greens into blues, posing blocks upon blocks"(Ibid.). But even more, as Liliane Louvel puts in a seminal contribution on writing and visuality, colours are the utmost challenge to words, both in everyday language (according to Wittgenstein) and in writing:

"I will start from the observation that, in the text/image report, the intermedial criticism, one of the stumbling blocks is precisely the rendering of the color, the most tactile and the most concrete of the materials of the plastic practices. Color worries the literary text, the threat of collapsing into impossibility, incommensurability. The Rider recalls that Valery wondered: and then, how to talk about colors?'

\section{Forms}

The painter's lesson, as will soon be clear, could be crucial to the novelist but only in terms of 'formal adventure'. Forms and methodslike landscape, anatomy, portraits- are tools and not facts, not 'the

ii This is specially the case of "Blue and Green", a daring piece with no trace of human presence and of narrative glimpses. On the subject see Sandra Cavicchioli “ Il silenzio della pittura. Analisi di due quadri di parole", in I sensi, lo spazio, gli umori e altri saggi, 2002; and Flora De Giovanni, La pagina e la tela. Intersezioni in Virginia Woolf, Napoli, Giannini editore, 2007, p.67-78.

iii Liliane Louvel. Écrire la couleur: un défi poétique. Histoires de bleu et de vert. Interfaces: image, texte, langage, Université Paris 7-Denis Diderot ; Presses de l'Université de Bourgogne, 2012, Defini- tions of color / de la couleur, vol. 33, p. 243-255. https://college.holycross.edu/interfaces/vol33. html, p. 243 world' in itself. The visual turn in Woolf's poetics is fully at work in many short stories. Short pieces are often intended by Woolf as formal exercises: a limited sequence of facts, a concentrated action, a study of character- simplicity might suits the short story better than the novel. In search of new forms of expression were also many painters. Two of them in particular seem close to Woolf's experimentation: Henry Matisse, who would speak for himself as in search of the "simple form", a pictorial essential sign devoid of emotional charges; and Walter Sickert, especially keen on exploring the intimate relationship between figures and the space. Not less relevant the intense relationship with her sister Vanessa Bell, whose studies on female portraits had an enormous impact on the writer's preoccupation with gaze and perspectives. ${ }^{6}$

However, as Woolf indicates in a letter to Jacques Raverat, better than painting the art of writing faces the tangle of life. Life exceeds every form, life is fluid, demanding a fluid form, being subjected to time, moving and passing with time. Then, from which perspectives or angle does the author offer the momentary life to her addressees? In discussing the parallel between Vanessa's practice of faceless figures and Woolf's theory about the unimportance of materialistic detail in fictional characterisation, Gillespie examines the different capabilities of the visual and verbal media to explore psychological depth; and then indicates the influence of Vanessa's art and aesthetic doctrine on Woolf's move towards a studied and formal modernism in fiction. ${ }^{\text {iv }}$ Other critics, like Maggie Humm, consider that, besides Vanessa, other artists also play an important role in Woolf's responses to art, in particular Walter Sickert. ${ }^{\mathrm{V}}$ In discussing a much more direct and extensive influence of Sickert's realist aesthetics on Woolf's fiction, Linden Peach shows similarities between them in their engagement with realist aesthetics. That is, both Sickert and Woolf create a fusion of the physical and the psychological in their respective work by pushing at the boundaries between physical surroundings, domestic objects and a range of expressions, gestures, moods and consciousness on the part of the individual. Peach equally indicates that this level of intimate relationship between figures and the space which they occupy is also recognised by Woolf herself in her essay, "Walter Sickert: Conversation": "Hence the intimacy that seems to exist in Sickert's pictures between his people and their rooms."

\section{Agonism and agonies in a short story}

It is within these contexts and networks that we turn in particular to a short piece- "In the Orchard" (1923). ${ }^{\text {vii }}$ in direct dialogue with the visual/formal 'secession' brought about by the avant-guarde art movements. There are also signs of gender hints implied in this narrative where a subject (a jeune fille), is found 'sensing' reality, processing her body and mind postures, testing perceptions and emotions. Under the gaze of different presences, invisible but detectable by the reader, an intangible force and a human eye are here summed up into a narrative voice that plays its writing game.

${ }^{\text {iv }}$ Alistair M. Duckworth. Review. The Sisters'Arts: The Writing and Painting of Virginia Woolf and Vanessa Bell. Diane Filby Gillespie. The Georgia Review, Vol. 44, No. 1/2, Women \& the Arts (Spring/Summer 1990), p. 315-318

"Maggie Humm. "Virginia Woolf and the Arts." The Edinburgh Companion to Virginia Woolf and the Arts. Ed. Maggie Humm. Edinburgh: Edinburgh University Press, 2010: p. 11.

viLinden Peach. "Virginia Woolf and Realist Aesthetics." The Edinburgh Companion to Virginia Woolf and the Arts. Ed. Maggie Humm. Edinburgh: Edinburgh University Press, 2010: p. 113.

vii“"In the Orchard" was published in 1923 on "The Criterion", April 23. The text is included in the volume V.Woolf, Books and Portraits, ed by M.Lyon, first published in 1977 by The Hogarth Press. For text quotations we refer here to the reprinted edition of 1982, published by Garland Press (p.15-17). 
Woolf sent to T.S. Eliot "In the Orchard", who had positevely commented on those sketches that followed the line of "Monday or Tuesday". Hermione Lee described it as "a mood piece of a young girl's day-dream written to resemble a post-impressionist painting"7 the last passage in particular resembled a post-impressionist painting ("and across the corner of the orchard the blue-green was slit by a purple streak"). In fact, in Woolf's fictional orchard, an elusive feminine figure is found at the centre of a prolonged process of perception and self-perception: Miranda is shown in a garden, abandoned to her reveries, 'testing' and 'tasting' her sensuous presence, adjusting her body to catch feelings, and measuring the sensuous space perceived around her. Behind the jeune fille, another presence - the author dislocated into the writing- is somewhere in the narrative scene. No landscape and no character- according to traditional literary standards- ever clearly emerge from the process, leaving the third actor- the reader- to a dream-like strip of images, attached to an I-less/eye-less monologue, vibrant with 'feminine notes'. Lost in her prismatic options, the character is at first shown in a synchronic a-topia resembling a cerebral coma rather than a living interval, while the narrative movement develops into recursive similar phrases that never sound fit to experience, generating a sense of frustration which, at its best, consigns all the staged subjects - here included the reader- to a sheer, almost grotesque resolution: the too conventional English afternoon tea that concludes the narrative effort. Outside the a-topias of visual instability, outside utopic gardens of art and dreams, life goes on undisturbed, and to this fluid something called 'life' the novelist will have to turn his/her attention, coping with the 'impure' tools of language and with the absence of a story.

On the other hand, "In the Orchard" exhibits its strong metafictional flavour, being the story of a formal gestation, of a writer's travel towards the counterdictions of writing life- the complexity of lifein a kind of multifaceted, open, suspended text. In this precise perspective, this short-story is a paramount example of a "try", both agonic and euphoric, the search of a form that aspires to a semplicity in a progressively polishing process, towards a less descriptive and more abstract form that recalls Matisse's and Cezanne's painting techniques.

The well known case of Matisse's search for a 'simple form' might be of specific relevance to the present discourse: we refer in particular to his famous painting "La Danse" (1909-1910), a series of odalisque figures where the apparently 'simple' and essential form of the female figure was indeed the result of twenty or more previous passages, a process of progressive polishing from emotional and individual teste in favour of abstraction. Reputed as a paramount example of Fauvism, the painting shows subjects designed at their most basic shapes and silhouettes, made almost into abstract signs imprinted in the three Matisse's favourite colours: blue, green and pink. Few direct citations are devoted to Matisse in Virginia Woolf's Letters or Essays viii, if not as one among the painters involved in that PostImpressionist Exhibition that so much intrigued Roger Fry and the Bloomsbury Group. Matisse's "Danse" and that intriguing 'simplicity' probably inspired Duncan Grant's art, and might have impacted on Woolf's formal experiments.

In particular, the idea of a formal gestation associated to a tentative narration is more than evident in the short stories of that experimental period more imbued of visual issues and pictorial atmospheres. It was in fact around the twenties that Woolf conceived landmarks

viii Woolf's direct remarks on Matisse and pictorial avant-guard are in "Pictures" (1925), Nation and Atheneum, April 25, and "Opening at the Roger Fry Memorial Exhibition, 18 September 1935", in The Moment and Other Essays, London, The Hogarth Press, 1947. such as "The Mark on the Wall" and "Kew Gardens", where an object or an episode are scrutinized, commented or remembered by characters/narrators who come and go within the narrative scene, with continuous interruptions and suspensions that consign text and sense to extreme fragmentation. In "In the Orchard", the idea of a narration 'in progress', interrupted and restarted, is even more explicit, as an attempt at sketching and re-sketching a scene at its best, or at its 'simplest': a sequence of three acts, where the same scene is presented thrice, with almost identical incipits and developing in three different micro-stories.

In her ample reviewing of Virginia Woolf's short stories, Christine Reynier acknowledges the self-reflexive core at the basis of the poetics of the short stories, textual spaces explicitely conceived to stage "the oirigin of the creative process". ${ }^{\text {x }}$ She devotes brief insights to "In the Orchard", but what comes out is the idea of a bald experiment, the design of a dynamic fictional space based on an unframing/framing process brought to its extreme consequences, though not devoid of "a sense of promise". The promise of a sense- one might adventure- in spite of deliberate formal disruptions and narrative de-regulations.

Frames can be on one side "efforts of containing fragmentation within a whole...they can be reduced to a minimal form, an enclosing sentence or frame marking the boundaries of a moment". ${ }^{7}$ In the case of "In the Orchard" two repeated sentences open and close the scenes, creating the effect of isolation or suspension of a moment: a moment of fiction focused on a span of time, which encloses "a moment of sleeping and dreaming, a moment of intimacy. Framing thus apparently turns the short story into a self-contained whole, a "cristal globe", a perfect shape."

And yet, "a continuous yet constantly interrupted movement demands an unfamiliar form of understanding and reading that should be sympathetic to it," imperceptibly leads the reader to see rather than read, Eyes are there to imagine, to be blind in front of words and open to the images embodied in the text, to resist too much an easy interpretation. Though at first sight "fragmented", "instable", "resistent", "In the Orchard" exhibits a "perfect structure" that inscribes it among those extreme agonisms that make certain short stories a perfect metatextual exercise aiming at challenging the narrator as well as the reader, or, in Reynier's words "a core surrounded by reflections, a solid object whose meaning is duplicated or multiplied. In any case the short story appears as a resting point from where the reader's mind can start speculating, drifting, interpreting, thus expanding the solid object into a plastic and dynamic one."

\section{I-sleeping/ I-awakening. Is there a subject in this text?}

"Miranda slept in the orchard": the same incipit inaugurates thrice the text. Three texts in one, but with differences. An experiment is on. In the very first line the reader encounters a supposedly 'sleeping I', feminine in name and sensuous in its dreaming movements. A sentence in French breaks the surface of an apparently silent landscape, a quotation from a book at Miranda's feet, as if resounding from afar: "ce pays est vraiment un des coins du monde où le rire des filles éclate le mieux" (p. 15). Miranda is sleeping but the world around her is not, emerging and flickering as if processed by someone or something else 'gazing', gently moving and 'touching' around: a gaze, a presence, intent on her attire, on details of the landscape, colours, sounds, echoes of voices caught from off-scene. Another hidden actor is hoovering-

${ }^{\mathrm{ix}}$ Christine Reynier, Virginia Woolf's Ethics of the Short Story, Palgrave, Macmillan, 2009, p.98. 
that makes Miranda's purple dress ripple "like a flower attached to a stalk" (p. 15). Not mentioned, a breeze is presiding now over the scene: at first very close to Miranda, then at a distance, then decidedly "above", moving freely, moving everywhere. This IT- this airy entitybecomes responsible of the only silent story apparently told here (or rather, blown here), and presides over the coming scene, master of the view, master of the textual scene. To this mysterious observer/actor a point of view is attached, "eyeless, brainless, meeting nothing that could stand against it" (p. 16, our emphasis). IT animates the clouds and the trees, IT hits and beats, carries sounds and cries, maybe some distant human cries, into the text: IT touches the world, and touches Miranda who "miles below, in a space as big as the eye of a needle" is abandoned to her sleep, herself eyeless but not earless, aware of the soft bustle around her.

In fact, the gaze-system and the hear system that constructs the sequence is not limited to the 'panoramic perspective' and the echoes in the air, it implies also a perspective from below and from inside, that might be- we understand- Miranda's one, though while sleeping, and/or of another actor 'listening' to and mediating Miranda's silent discourses and hyper-sensitive mental perceptions. From below, and in her reverie, Miranda seems to be dancing imaginatively with the apples swinging and glittering in the wind, herself the image of an eyeless character; only, from the bottom and not from above. Miranda's reverie points to a spatial perception which we can surmise from her movements; quoting from Sandra Cavicchioli's seminal reading:"

"we are faced with an elastic, pliable space, apparently perceived primarily through touch, where the boundaries between subject and outer world are blurred. Sounds therefore combine to build up space as an acoustic experience that is multidirectional, disseminated, and devoid of thresholds". ${ }^{x}$

When the wind stops blowing "from south to east", wheeling the other way, everything changes, the whole scene is going to change, and Miranda stands suddenly upright, crying aloud her first and only 'down to earth' thought: "Oh, I shall be late for tea" (p. 16). On this apparently frivolous statement, if measured on the limited context, the first sequence stops. When it starts again, the scene has not apparently changed: again, "Miranda slept in the orchard", but the words that follow open to new narrative options: "or perhaps she was not asleep" (p.16), though her lips move almost mechanically- or musically- repeating the word "éclat", as to prolongue "le rire des filles". The second sequence re-processes the first scene on different premises. Miranda is the mastering gaze now, the active agent: the sounds heard from afar are in fact whispers from her lips: "she smiled", "she thought", "she sighed", and she fancies, and in the first person: "I might be....". She is the centre around which the world is organized, the eye through which other men and women are seen, the potential organiser of a story: "she traced out the lines...made over the countryside until they all seemed driven out, round and across by the beat of her heart" (p. 17, our emphasis). No longer eyeless, or disembodied and airy, the gaze that processes the scene is attached to a body that 'speaks': sensuous, ecstatic or reactive according to her

${ }^{x}$ Sandra Cavicchioli, "I sensi, lo spazio, gli umori. Micro-analisi di In The Orchard di Virginia Woolf", in VS, Quaderni di Studi Semiotici, 57, 1990. our translation- ("ci troviamo di fronte a uno spazio elastico e deformabile, percepito, sembra, in modo eminentemente tattile, in cui i confini tra il soggetto e il mondo esterno si fanno incerti. I suoni partecipano ora a una costruzione dello spazio come spazio acustico, che si rivela multidirezionale, privo di soglie, diffuso.") changing mood, hypersensitive and melodramatic: "she thought that she heard life itself crying out from a rough tongue in a scarlet mouth" (p. 16). ${ }^{10-14}$

The whole world lives now through Miranda's sensuous body, pulses with her heart's rhythm:

"Everything had already begun moving, crying, riding, flying round her, across her, towards her in a pattern....Mary is chopping the wood, she thought; Pearmen is herding the cows" (p.17). A few lines, and the sequence stops again at the point of Miranda being worried again about her afternoon tea. A third and final sequence begins, and again "Miranda slept in the orchard", while a voice off-stage is asking whether she is really sleeping or not. The world around merges as the strange mixture of a landscape conceived by a careful gardener and a visionary scene processed by a half-awake mind. The text now embodies a gaze that seems to know well how to play with forms: Miranda's purple dress matches perfectly the two apple-trees nearby (whose fruit, we imagine, are red): there are twenty four apples in the foreground (like in a giant and grotesque Cezanne painting) neatly arranged in rows and groups, with colour that answers to colour and bodies to bodies. Every form answers to another form, all forms almost geometrically distributed in perfect proportion and balance: "Each apple-tree had sufficient space. The sky exactly fitted the leaves" and "the whole was compacted by the orchard walls" (p. 17), as if the implied gaze was playing with a mock-Cubist vision. Miranda eventually again remembers her tea (but her exclamation is here put in parenthesis), while the wind beats the four corners of the orchard, violently tossing the apple-branches, disturbing men and animals, if any. The concluding passage is reminiscent of a still surface suddenly broken, a battle of colours is on ("across the corner of the orchard the blue-green was slit by a purple streak", p.17), as a living entity is imposing itself on a natural landscape formerly repatterned into a still-life. ${ }^{15}$

Because of its structure and the numerous allusions to a selfreflective process, "In the Orchard" is easily perceivable as a text explicitly suggesting the ambition of a cognitive adventure: this orchard is a spot where the only story really told is that of the relationship between a subject and the space around it, and that of the way a gaze can organize a space into a tale or a canvas. Actually Cavicchioli recognised in this short piece an outstanding cognitive experiment where writing aims to measure the emotional impacts attached to subjects exposed to the 'living' world- where the experience similarly engages a character-narrator (doubly entailed as object and subject of the narration) and a reader. ${ }^{16}$

\section{Echoes in a locus amoenus}

Eventually, Miranda expresses, in her sweet abandonment, a desire to have access to 'another scene'. The second sequence opens up to new abstracted options and the text intercepts imaginaries that displace the scene, mimicring a musical environment. Sounds can now jump onto the page in simultaneous cadence: collections of sounds combined with splashes of colour, images where forms blend into new and strange conglomerates; boundaries have collapsed, 'in' and 'out' are seen as a continuum (heartbeats echo bell tolls, breath and wind pace together). Sounds sweep through Miranda, surround her, trespass her: in contrast to the third sequence, where sounds are cancelled. In the third sequence, we are confronted with a scene where both the observer and the observed object are 'purified': reality is processed as if on a painted canvas, the observed object is reduced to a grotesque 
geometry of apples. Miranda, whose presence is uncertain but totally neutral, evaporates, becoming a purple streak in the background, not a figure but a cut in the canvas. Once the world has been made voiceless and the subject eyeless, the author's next move is to lessen the figurative impact in favour of a rigidly structured figuration: trees that point high, birds that fly low, the wind wavering on the surface of the earth, the orchard compacted by the wall. The text lies in front of us, a perfect metatextual device related to an image that merely plays with forms, icons of form (the apples) geometrically distributed and harmonically recomposed. Now the orchard ironically mimics a room, an enclosed space where a perceptive act is performed, entirely 'receptive' although endowed with an aesthetic quality. ${ }^{17}$

Thus, if we were to extract a poetic 'moral' from the opening lines of the last sequence, we would say that "In the Orchard" objective contemplation is possible only 'in ecstasy', somehow eyeless, when the subject is 'vacant' at both the cognitive and social levels (forgetting books and afternoon-teas). A purely aesthetic emotion is now merging from the text: a order, a strong architecture, a voiceless and eyeless energy able to generate meaning in the almost total absence of a story. Until the wind comes again, breaking the surface of the scene. Life, subjected to time, to moving and to time passing, defies formal gestures, in its fluidity it demands a fluid form. That same fluidity invests the subject, here shown in its agonistic plurality. ${ }^{18}$

"In the Orchard" character and narrator dislocate into many different figures (even in 'the wind'), staging a cognitive agon and an aesthetic agonism; this quite unusual text closes in on a subject assigned to an 'absence' which allows the experience of being 'out of oneself': in the guise of many selves, out of themselves, a (woman) writer and a mask called Miranda experience the world as a breath of life (embodied in the phantom presence of the wind and in a vibrating female body), as well as a glimpse of beauty (of sounds, colours and forms provisionally geometrically arranged). Life is however calling, at the end, and even the drowsy Miranda will wake up- though social life is put in a parenthesis, not eliminated but set in the background. Life is calling and a woman answers: une fille is at the centre of narration and at the centre of the spatial processing ("Ce pays est vraiment un des coins du monde où le rir e des filles éclate le mieux"). The girl's name- Miranda- and the given spatial context- in a locus amoenus unconventionally sketched, on the grass, under the treesinscribe the fille in a rich and recognisable literary genealogy. ${ }^{19}$

Herself une fille, in all her sensuous presence, a young author projects herself onto the literary world, directing herself and the readers towards the shores of a "brave new world', "où le rire des filles éclate le mieux", and "through the looking glass", in the multistrata reality of the self. A gender vibration closes the text, showing a Miranda eventually well awaken, now a full subject with her fantasies and ruminations: the world she was dreaming of will not be a simple quotation (the quotation has in fact disappeared). There is actually a "sense of promise" in this open ending. What 'life' is beyond that orchard might be the matter of a fourth sequence, another scene, the unwritten one.

\section{Acknowledgments}

None.

\section{Conflicts of interest}

The author declares that there is no conflict of interest.

\section{Funding}

None.

\section{References}

1. The Letters of Virginia Woolf (1888-1941). In: Nicolson N,Joanna Trautman, Editors. London, The Hogarth Press. 1975-80.

2. Books and Portraits. In: Lyon M, Editor. London, Garland; 1982.

3. Woolf V. The Common Reader. London, The Hogarth Press. 1945.

4. The Essays of Virginia Woolf. In: Woolf L, Editor. vol.II, London, The Hogarth Press; 1967.

5. The Moment and Other Essays. New York, Harcourt Brace Jovanovich. 1948.

6. Lee H. Virginia Woolf. London, Vintage; 1996.

7. Reynier C. Virginia Woolf's Ethics of the Short Story, Palgrave, Macmillan; 2009.

8. Vanessa Bell, Virginia Woolf. Draw life. Ferrara, Sate; 1996.

9. Cavicchioli S. Sandra Cavicchioli. I senses, space, moods. Micro-analysis of "In The Orchard” by Virginia Woolf". Semiotic Study Papers. 1990. 57.

10. De Giovanni F. The page and the canvas. Intersezioni in Virginia Woolf. Napoli, Giannini editore. 2007.

11. Duckworth AM. Review. The Sisters' Arts: The Writing and Painting of Virginia Woolf and Vanessa Bell. Diane Filby Gillespie. The Georgia Review. Women \& the Arts. 1990;44(1/2).

12. Dunn J. A very close conspiracy. Vanessa Bell and Virginia Woolf. London, L. Cape; 1990.

13. Gillespie DF. The Sisters Arts: The Writing and The Writing and painting of Virginia Woolf and Vanessa Bell. Syracuse, Syracuse University Press. 1988.

14. Humm M. Virginia Woolf and the Arts. The Edinburgh Companion to Virginia Woolf and the Arts. In: Maggie Humm, Editor. Edinburgh, Edinburgh University Press. 2010.

15. Linden P. Virginia Woolf and Realist Aesthetics. The Edinburgh Companion to Virginia Woolf and the Arts. In: Maggie Humm, Editor. Edinburgh: Edinburgh University Press. 2010.

16. Louvel L. Poetics of the Iconotext. Edited by Karen Jacobs, translated by Laurence Petit. Burlington. VT, Ashgate; 2011.

17. Holy Cross. Write the color: a poetic challenge. Stories of blue and green. Interfaces: image, text, language. University Paris 7-Denis Diderot; Presses of the University of Burgundy. 2012;33:243-255.

18. The Hogarth Press. 1947.

19. The Essays of Virginia Woolf. (CE). In: McNeillie, Editor. London. The Hogarth Press. 1986-88;1-4. 